\title{
Vihannesketjun kehittäminen -hankkeen (VIKKE) lajikekokeiden satoa vuodelta 2011
}

\author{
Veikko Hintikainen $^{1)}$, Anne Tillanen ${ }^{2)}$, Anne Piirainen ${ }^{3)}$, Hanna Avikainen $^{3)}$ \\ ${ }^{1)}$ M TT Kasvintuotannon tutkimus, Lönnrotinkatu 3, 50100 M ikkeli, veikko.hintikainen@ mtt.fi \\ ${ }^{2)}$ M TT Kasvintuotannon tutkimus, Lönnrotinkatu 5, 50100 Mikkeli, anne.tillanen@mtt.fi \\ ${ }^{3)}$ Helsingin yliopisto, Ruralia-instituutti, Lönnrotinkatu 7, 50100 M ikkeli, anne.piirainen@ helsinki.fi, \\ hanna.h.avikainen@helsinki.fi
}

\section{Tiivistelmä}

Suomessa avomaan vihanneksilla ei ole virallista lajikekoetoimintaa. Siitä syystä lajikekokeita tehdään eripuolilla Suomea toimivissa maaseudun kehittämishankkeissa. Jonkin verran lajikekokeiluja tekevät myös yksittäiset vihannesviljelijät.

Helsingin yliopiston Ruralia-instituutin hallinnoimassa Vihannesketjun kehittäminen -hankkeessa (VIKKE) on vuosien 2008-2011 aikana tehty lajikekokeita hankkeessa mukana olevilla vihannestiloilla niillä avomaan vihanneksilla, jotka alueen viljelijöille ovat tärkeitä eli jäävuorisalaatilla, kiinankaalilla ja parsakaalilla. Tässä esitetyt tulokset ovat mainituilta vihanneksilta vuodelta 2011.

Jäävuorisalaattikokeessa oli mukana kymmenen lajiketta: numerolajikkeet 45-32 RZ, 45-48 RZ, 45-58 RZ ICE 14113 Vil, ICE 15241 Vil, ICE 16870 Vil sekä Templin Nun, Gondar Nun, Expression EZ ja verrannelajikkeena Creation EZ. Kauppakelpoiset sadot vaihtelivat 19391-29029 kg/ha lajikkeesta riippuen. Satoisimpia olivat lajikkeet 45-32 RZ ja ICE 14113. Kaikissa kokeen lajikkeissa esiintyi salaatinpiilomätää (Pseudomonas cichorii), joka enimmillään tuhosi ICE 16870 sadosta $30 \%$. Koska monet jäävuorisalaattilajikkeet ovat olleet kokeissa vasta yhtenä tai kaksi kasvukautena, niin koetuloksiin on syytä suhtautua varauksella.

Parsakaalikokeessa testattiin varhaistuotantoon sopivia lajikkeita. Lajikkeita oli kokeessa kahdeksan: numerolajike SGD 4352 SI S\&G sekä Sirtaki CL, Koros CL, Aquiles Sak, Chronos Sak, Milady Seminis, Fellow Seminis ja verrannelajike Batavia BZ. Kauppakelpoiset sadot vaihtelivat 7285-12200 kg/ha. Sirtakista saatiin selvästi paras sato ja sen kukinnot olivat myös painavimmat, keskipaino $400 \mathrm{~g}$. Seuraavina olivat numerolajike SGD 4352 SI ja Koros. Heikoimmat sadot antoivat Milady ja Chronos. Kaikkien lajikkeiden kauppakelpoisuus oli korkea eli yli $90 \%$. Parsakaalilajikkeista Koros ja Chronos ovat olleet kokeissa kahtena tai kolmena vuonna ja niistä on hyviä kokemuksia niin sadon määrän kuin laadunkin suhteen. Sirtakin viljely on suositeltavaa sen lyhyen kasvuajan vuoksi.

Kiinakaalikokeessa etsittiin uusia varastointiin sopivia lajikkeita. Lajikkeita kokeessa oli viisi: TEHA 037 Taki, Suteki Sak, Tabaluga Sak, numerolajike SK 11-55 Sak, ja verrannelajike Suprin S\&G. Parhaan sadon antoi Suteki ja heikoimman verrannelajike Suprin. Kauppakelpoiset sadot vaihtelivat 34753-49842 $\mathrm{kg} / \mathrm{ha}$. Numerolajike SK 55-11 lukuun ottamatta muista koelajikkeista on kahden vuoden kokemukset. Kasvukausien 2010 ja 2011 tulokset ovat ristiriidassa keskenään. Tuloksien luotettavuuden varmistaminen vaatii lisää lajikekokeita.

\section{Asiasanat}

Jäävuorisalaatti, Lactuca sativa var. capitata, Parsakaali, Brassica oleracea var. italica, kiinankaali, Brassica rapa ssp. pekinensis, lajikkeet, lajikekokeet 


\section{Johdanto}

Suomen avomaan vihanneksien tuotantoala oli vuonna 20108654 ha , sisältäen herneen viljelyalan (Puutarha tilastot 2010). Tärkeimpiä tuotantoalueita ovat Varsinais-Suomi, Satakunta, Häme, Uusimaa ja Etelä-Savo. Etelä-Savon alueella tuotettiin viime vuonna 70 \% Suomen kiinankaalista, $53 \%$ jäävuorisalaatista ja $25 \%$ parsakaalista. Alueella hehtaarikohtaiset satotasot ovat valtakunnallisesti vertailtuna korkeita ammattimaisen ja tehokkaan tuotannon ansiosta. Tuotanto suuntautuu pääasiassa tuoremarkkinoille.

Suomessa avomaan vihanneksilla ei ole virallista lajikekoetoimintaa. Tämän vuoksi lajikekokeita tehdään eripuolilla Suomea toimivissa maaseudun kehittämishankkeissa. Jonkin verran lajikekokeiluja tekevät myös yksittäiset vihannesviljelijät.

Helsingin yliopiston Ruralia-instituutin hallinnoimassa Vihannesketjun kehittäminen -hankkeessa on vuosien 2008-2011 aikana tehty lajikekokeita hankkeessa mukana olevilla vihannestiloilla niillä avomaan vihanneksilla, jotka alueen viljelijöille ovat tärkeitä eli jäävuorisalaatilla, kiinankaalilla ja parsakaalilla. Tässä esitetyt tulokset ovat mainituilta vihanneksilta vuodelta 2011.

\section{Aineistot ja menetelmät}

\section{Jäävuorisalaatti (Lactuca sativa var. capitata)}

Jäävuorisalaatin lajikekoe perustettiin Joroisiin. Koe ajoitettiin siten, että sadonkorjuu tapahtui salaatin sadonmuodostuksen "stressiaikaan" eli heinäkuun puolesta välistä elokuun puoleenväliin. Lajikkeita kokeessa oli kymmenen: numerolajikkeet 45-32 RZ, $45-48$ RZ, 45-58 RZ ICE 14113 Vil, ICE 15241 Vil, ICE 16870 Vil sekä Templin Nun, Gondar Nun, Expression EZ ja verrannelajikkeena Creation EZ. Koelajikkeet kylvettiin Plantek 144 -kennoihin 17.5. Viljelijä huolehti taimien kasvatuksesta. Taimet istutettiin peltoon 19.6. kolmeen riviin/raideväli tilan oman salaattilohkon keskelle. Taimietäisyys oli $23 \mathrm{~cm}$ ja taimimäärä noin $80000 \mathrm{kpl} / \mathrm{ha}$. Viljelijä hoiti kokeen tilan viljelykäytäntöjen mukaisesti.

Sato korjattiin neljältä näytealalta/lajike. Yhden näytealan pinta-ala oli $4 \mathrm{~m}^{2}$. Koealaan otettiin mukaan kaikki raidevälin kolme riviä. Noston yhteydessä kerät kauppakunnostettiin ja siirrettiin sisätiloihin tarkempaa analysointia varten. Sato lajiteltiin kauppakelpoisiin ja kauppakelvottomiin seuraavasti:

1. Kauppakelpoiset kerät: 300-450 g, 450-600 g, >600 g

2. Kauppakelvottomat kerät: < 300g, tautien pilaamat, tuholaisten vioittamat, lehdenreunapoltteiset, kukkavartiset

Jokaisen sadonlajitteluluokan kerien lukumäärä laskettiin ja luokkien kerien yhteispaino punnittiin. Jokaisen näytealan kauppakelpoisista keristä valittiin painoluokkien suhteessa seitsemän kerää, jotka halkaistiin ja niistä arvioitiin kerän kiinteys ja muoto, lehdenreunapolteen esiintyminen ja kukkavarren muodostuminen asteikolla 1-9. Saadut satotulokset esitetään näytealojen keskiarvoista laskettuina hehtaarisatoina.

\section{Parsakaali (Brassica oleracea var. italica)}

Parsakaalin lajikekoe perustettiin Haukivuorelle. Kokeessa testattiin varhaistuotantoon sopivia lajikkeita. Lajikkeita kokeessa oli kahdeksan: numerolajike SGD 4352 SI S\&G sekä Sirtaki CL, Koros CL, Aquiles Sak, Chronos Sak, Milady Seminis, Fellow Seminis ja verrannelajike Batavia BZ. Koe perustettiin ostotaimilla, jotka kylvettiin käsin Plantek 144 -kennoihin 23.3. Koe istutettiin peltoon 6.5. kolmeen riviin/raideväli tilan oman parsakaali lohkon keskelle. Taimimäärä oli noin $33000 \mathrm{kpl} / \mathrm{ha}$. Viljelijä hoiti kokeen tilan viljelykäytäntöjen mukaisesti.

Sato korjattiin kolmelta näytealalta/lajike. Yhden näytealan pinta-ala oli $10 \mathrm{~m} 2$, käsittäen kaikki raidevälin kolme riviä. Sadonkorjuu kertoja 2-3 lajikkeesta riippuen ja sadonkorjuu kesti ajallisesti viikon. Sadonkorjuun yhteydessä kukinnot kauppakunnostettiin ja siirrettiin sisätiloihin tarkempaa analysointia varten. Sato lajiteltiin kauppakelpoisiin ja kauppakelvottomiin seuraavasti:

1. Kauppakelpoiset kukinnot: $6-8 \mathrm{~cm}, 8-10 \mathrm{~cm}, 10-12 \mathrm{~cm}, 12-4 \mathrm{~cm},>14 \mathrm{~cm}$

2. Kauppakelvottomat kukinnot: $<6 \mathrm{~cm}$, tautien pilaamat, tuholaisten vioittamat

Jokaisen sadonlajitteluluokan kukintojen lukumäärä laskettiin ja luokkien kukintojen yhteispaino punnittiin. Saadut satotulokset esitetään näytealojen keskiarvoista laskettuina hehtaarisatoina. 


\section{Kiinankaali (Brassica rapa ssp. pekinensis)}

Etelä-Savossa kiinankaalia viljellään pääasiassa varastovihanneksena. Tämän vuoksi lajikekoe toteutettiin varastolajikkeilla. Lajikekoe perustettiin Joroisiin. Lajikkeita kokeessa oli viisi: TEHA 037 Taki, Suteki Sak, Tabaluga Sak, numerolajike SK 11-55 Sak, ja verrannelajike Suprin S\&G. Koelajikkeet kylvettiin Plantek 144 -kennoihin 30.6. Viljelijä huolehti taimien kasvatuksesta. Taimet istutettiin peltoon 28.7. kolmeen riviin/raideväli tilan oman kiinankaalilohkon keskelle. Taimimäärä oli $67000 \mathrm{kpl} / \mathrm{ha}$. Viljelijä hoiti kokeen tilan viljelykäytäntöjen mukaisesti.

Sato korjattiin neljältä näytealalta/lajike. Yhden näytealan pinta-ala oli $4 \mathrm{~m}^{2}$, käsittäen kaikki raidevälin kolme riviä. Noston yhteydessä kerät kauppakunnostettiin ja siirrettiin sisätiloihin tarkempaa analysointia varten. Sato lajiteltiin kauppakelpoisiin ja kauppakelvottomiin seuraavasti:

1. Kauppakelpoiset kerät: $0,5-1,0 \mathrm{~kg}, 1,0-1,5 \mathrm{~kg},>1,5 \mathrm{~kg}$

2. Kauppakelvottomat kerät: $<0,5 \mathrm{~kg}$, tautien pilaamat, tuholaisten vioittamat, lehdenreunapoltteiset, kukkavartiset

Jokaisen sadonlajitteluluokan kerien lukumäärä laskettiin ja luokkien kerien yhteispaino punnittiin. Jokaisen näytealan kauppakelpoisista keristä valittiin painoluokkien suhteessa seitsemän kerää, jotka halkaistiin ja niistä mitattiin kerien korkeudet sekä arvioitiin kerien kiinteys, lehdenreunapoltteen esiintyminen ja kukkavarren muodostuminen asteikolla 1-9. Saadut tulokset esitetään näytealojen keskiarvoista laskettuina hehtaarisatoina

\section{Tulokset ja tulosten tarkastelu}

\section{Jäävuorisalaatti (Lactuca sativa var. capitata)}

Jäävuorisalaattikokeen lajikkeista useimmat olivat ensimmäistä tai toista kertaa kokeessa. Jäävuorisalaattikokeen lajikkeiden sato korjattiin 25.-28.7.. Lajikkeiden kasvuaika istutuksesta sadonkorjuuseen vaihteli 39-42 vuorokauden välillä.

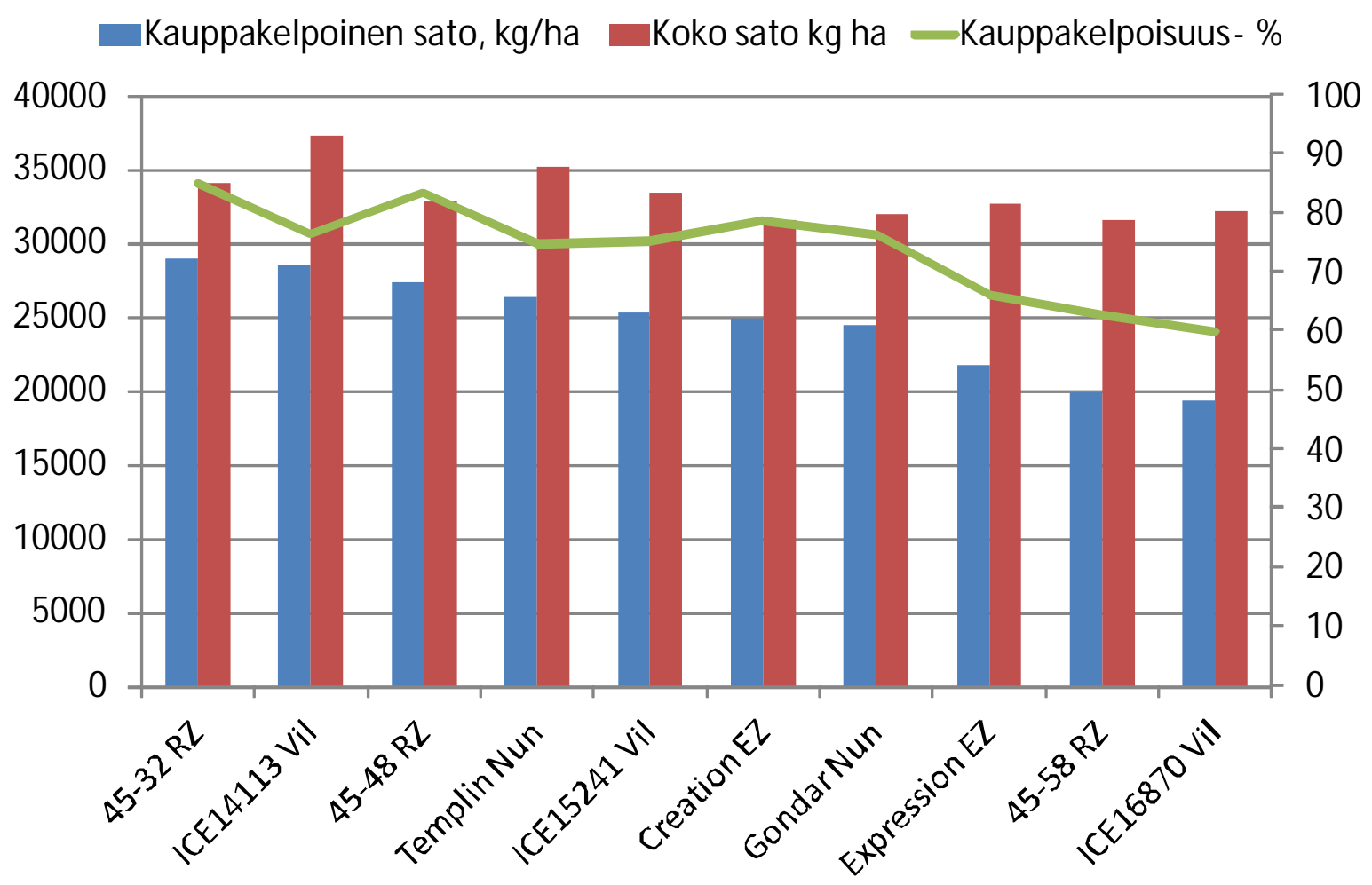

Kuva 1. Jäävuorisalaattilajikkeiden koko sato, kauppakelpoinen sato ja kauppakelpoisuus- \% 
Satoisimpia olivat numerolajikkeet 45-32 RZ ja ICE 14113. Heikoimmat sadot tuottivat numerolajikkeet 4558 RZ ja ICE 16870 (Kuva 1). Paras kauppakelpoisuus oli lajikkeilla 45-32 RZ ja 45-48 RZ (Kuva 1).

Kaikissa kokeen lajikkeissa esiintyi salaatinpiilomätää (Pseudomonas cichorii) (Kuva 2), joka enimmillään tuhosi ICE 16870 sadosta $30 \%$ ja pudotti kauppakelpoisen sadon määrän alle $70 \%$. Näyttää siltä, että salaatinpiilomädästä on tullut kuumien ja kuivien kasvukausien ongelma. Muista kasvitaudeista ei ollut merkittävää haittaa. Kukkavarsisuutta ja lehdenreunapoltetta ei esiintynyt. Kiinteyden ja muodon perusteella kaikki lajikkeet sopivat tuoremyyntiin.

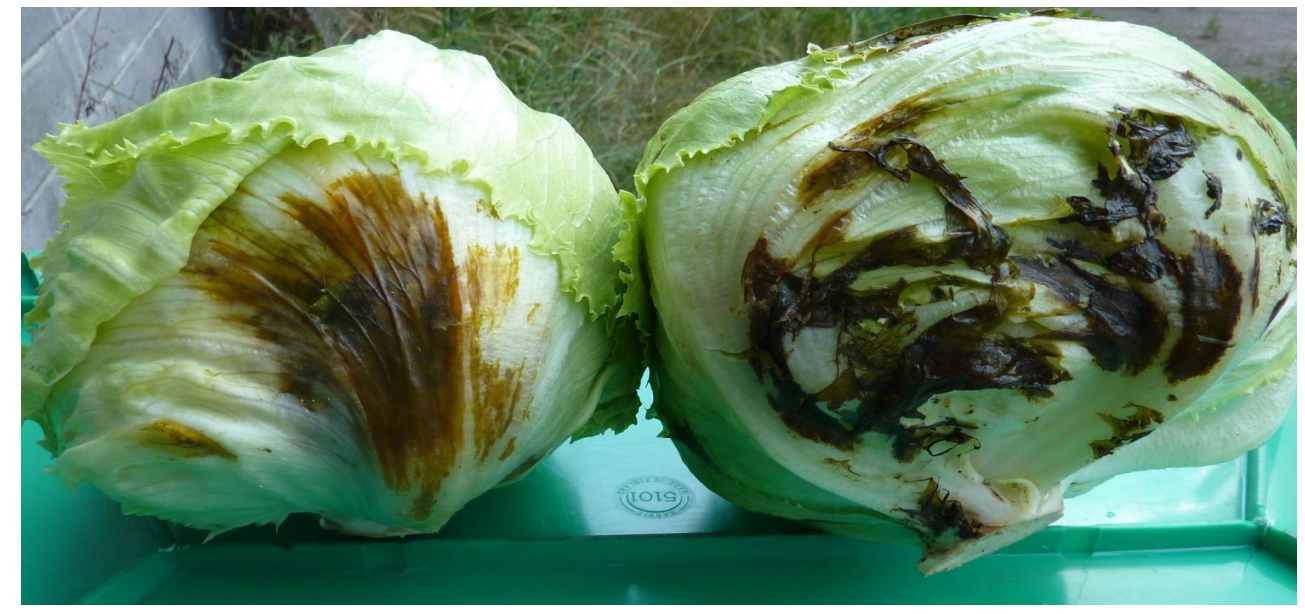

Kuva 2. Salaatin piilomätä (Pseudomonas cichorii). Jäävuorisalaatin lajikekokeen pahin kasvitauti (Kuva: Veikko Hintikainen)

Parsakaali (Brassica oleracea var. italica)Parsakaalilajikkeiden sadonkorjuu tapahtui 6.-13.7. välisenä aikana. Lajikkeiden kasvuajat istutuksesta sadonkorjuuseen vaihtelivat 61-66 vuorokauteen. Nopeinta kehittyminen oli Sirtakilla (Kuva 4).

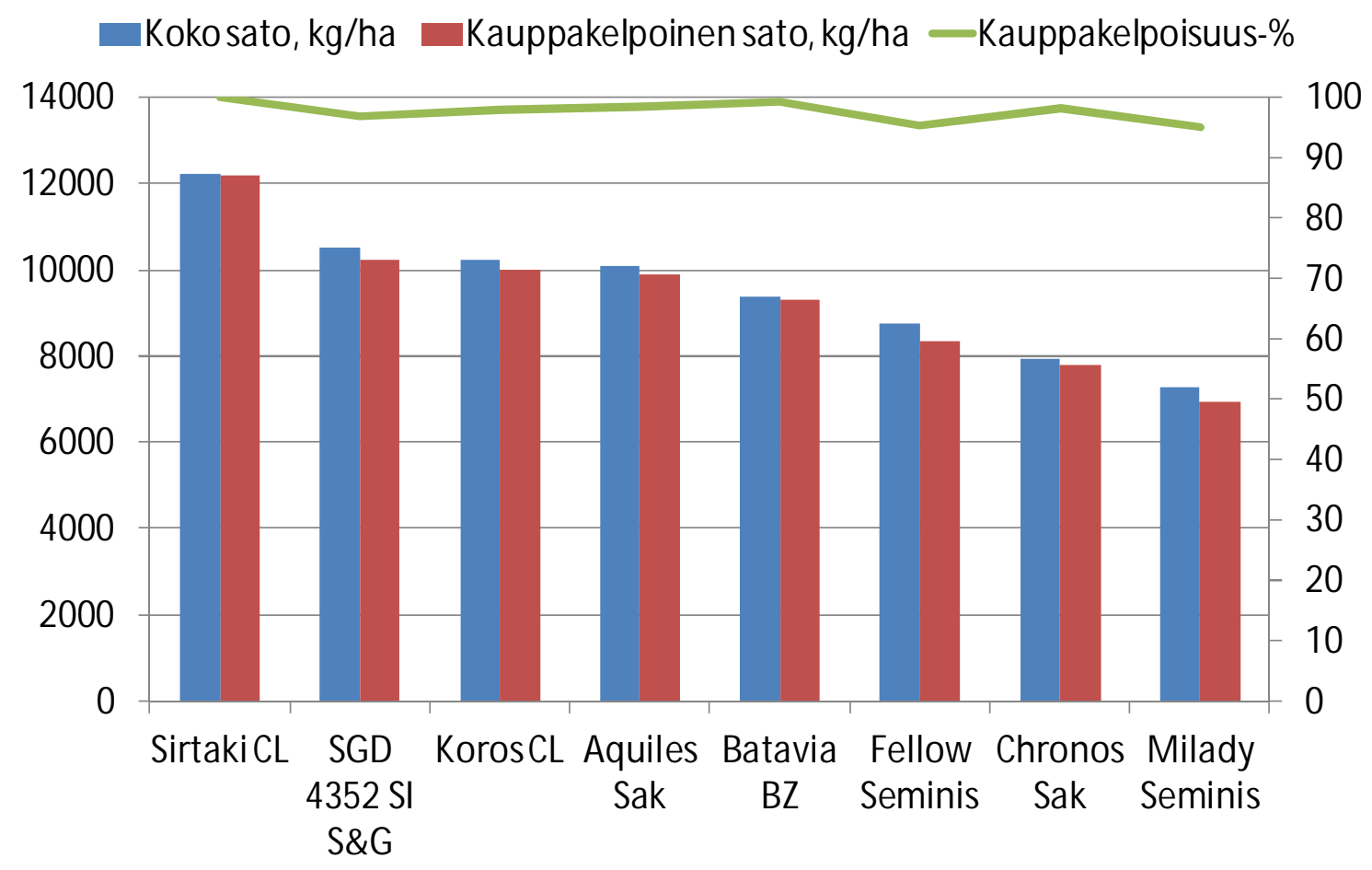

Kuva 3. Parsakaalilajikkeiden koko sato, kauppakelpoinen sato ja kauppakelpoisuus- \% 
Sirtakista saatiin selvästi paras sato (Kuva 3) ja sen kukinnot olivat myös painavimmat, keskipaino $400 \mathrm{~g}$. Seuraavina olivat numerolajike SGD 4352 SI ja Koros. Heikoimmat sadot antoivat Milady ja Sirtaki. Kaikkien lajikkeiden kauppakelpoisuus oli korkea eli yli $90 \%$ (Kuva 3). Lajikkeista kukintojen laadussa erottuivat SGD 4352 SI, Koros ja Chronos, joiden kukinnot olivat hyvin kuperia ja lievästi poimuisia. Sen sijaan Miladyn, Fellowin ja Aquilesin kukinnot olivat runsaspoimuisia ja osittain floretit irti toisistaan. Verrannelajike Batavian ja Sirtakin kukinnot olivat litteitä ja niissä oli vettä kerääviä poimuja. Poimuihin kerääntyvä vesi nopeuttaa kukinnon pilaantumista.

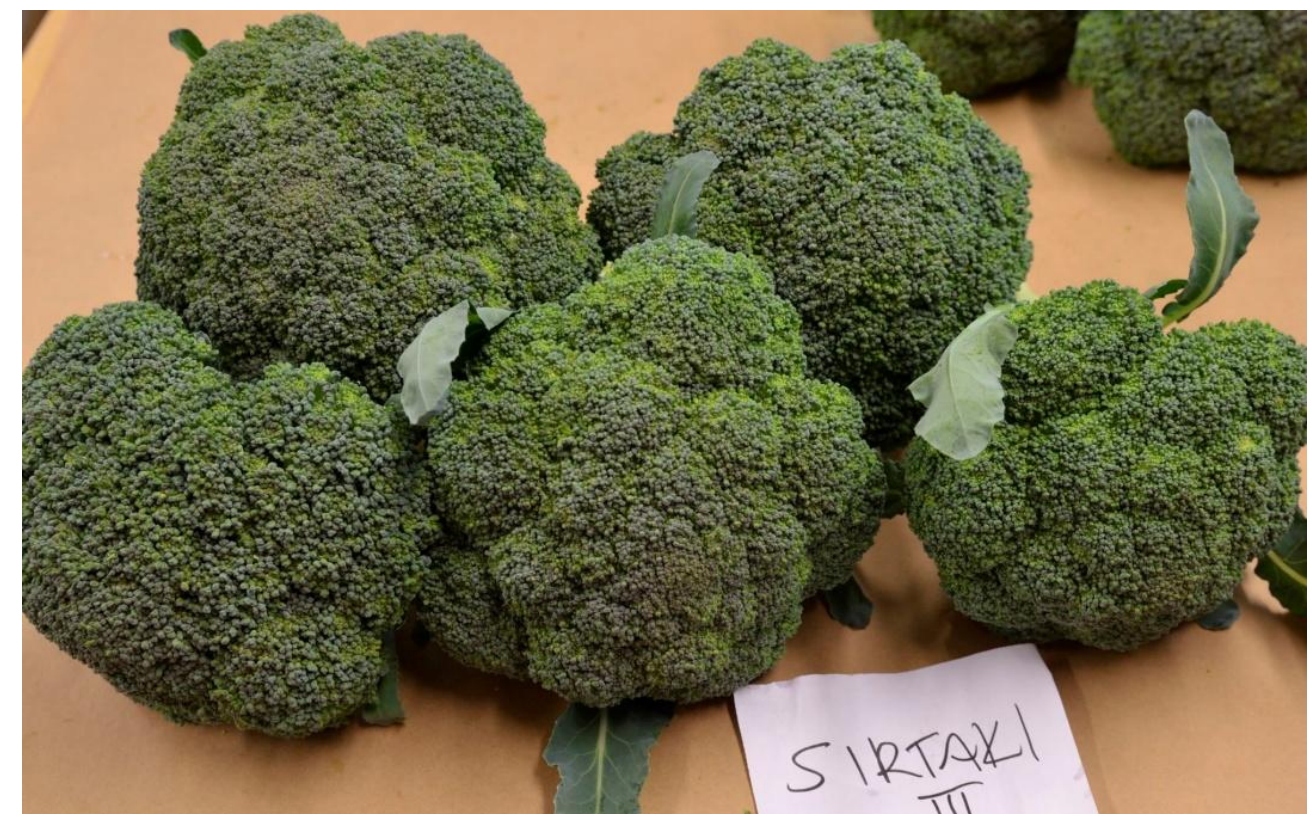

Kuva 4. Sirtaki oli parsakaalikokeen satoisin lajike (Kuva: Anne Piirainen)

\section{Kiinankaali (Brassica rapa ssp. pekinensis)}

Kiinankaalikokeen lajikkeet olivat toista vuotta kokeessa numerolajike SK 55-11 lukuun ottamatta. Vuoden 2010 kasvukaudella kaikki lajikkeet kasvoivat erinomaisesti ja sadon laatu oli korkea, mutta varastoinnin kestivät vain TEHA 037 ja verrannelajike Suprin.

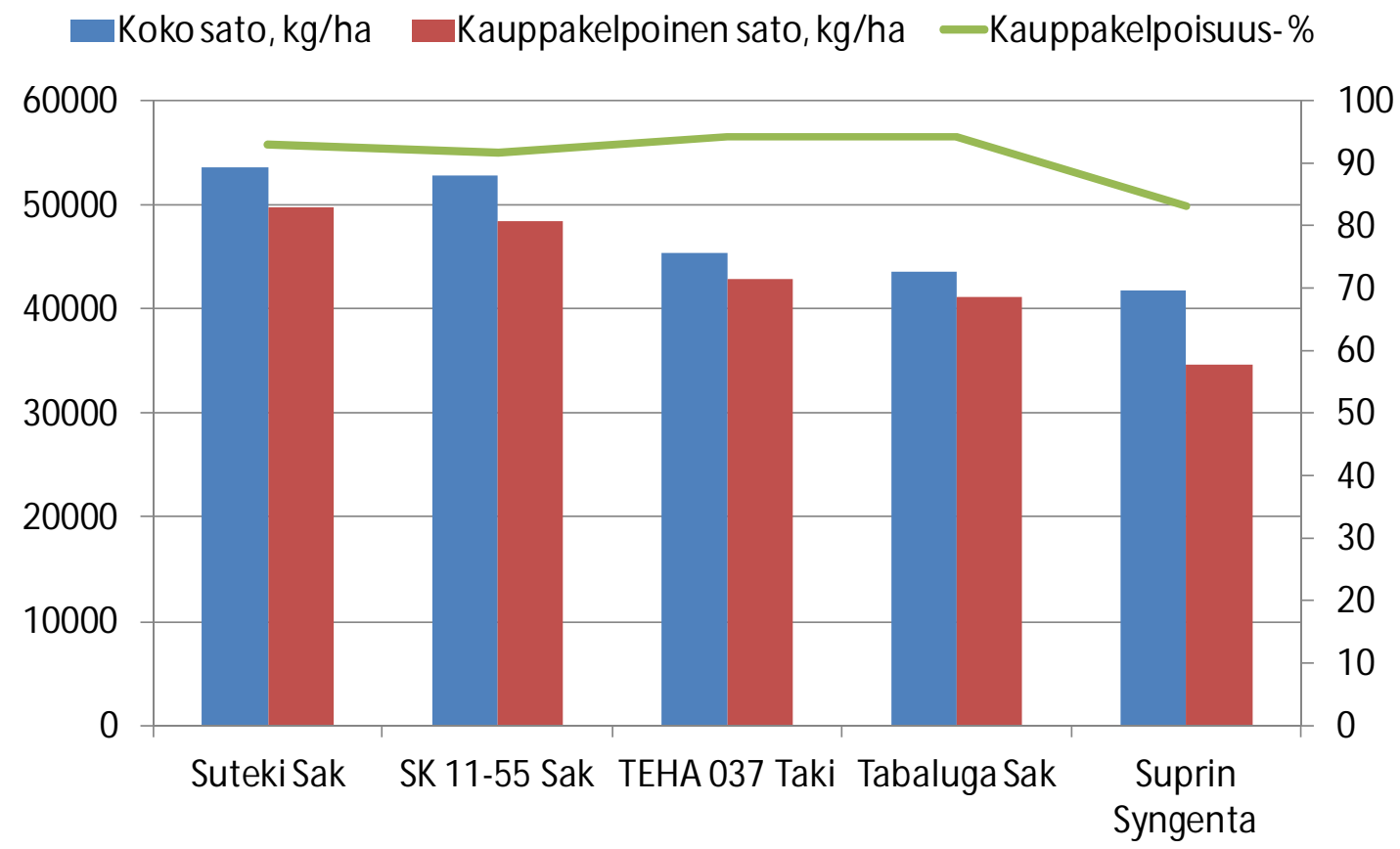

Kuva 5. Kiinankaalilajikkeiden koko sato, kauppakelpoinen sato ja kauppakelpoisuus- \% 
Kasvukaudella 2011 lajikkeiden sato korjattiin 19-22.9. Keskimääräiseksi kasvuajaksi istutuksesta sadonkorjuuseen tuli 55 vuorokautta. Suurimmat kauppakelpoiset sadot saatiin Sutekista ja SK 11-55 (Kuva 5). Heikoimmin menestyi verranne lajike Suprin, jota vaivasi lehtien reunojen ruskettuminen ja niin ikään lehden reunoihin kehittyneet mustat pisteet (Kuva 6). Samoja ongelmia oli myös TEHAlla. Muodoltaan Sutekin kerät olivat erikoisen pulleita, mikä saattaa vaikeuttaa niiden pakkaamista tuorekauppaan. SK 11-55 ja Tabaluga olivat muodoltaan myös pulleita, mutta hyvin kiinteitä. TEHAn ja Suprinin kerien muoto oli lieriömäinen ja ne olivat muita koelajikkeita korkeampia.

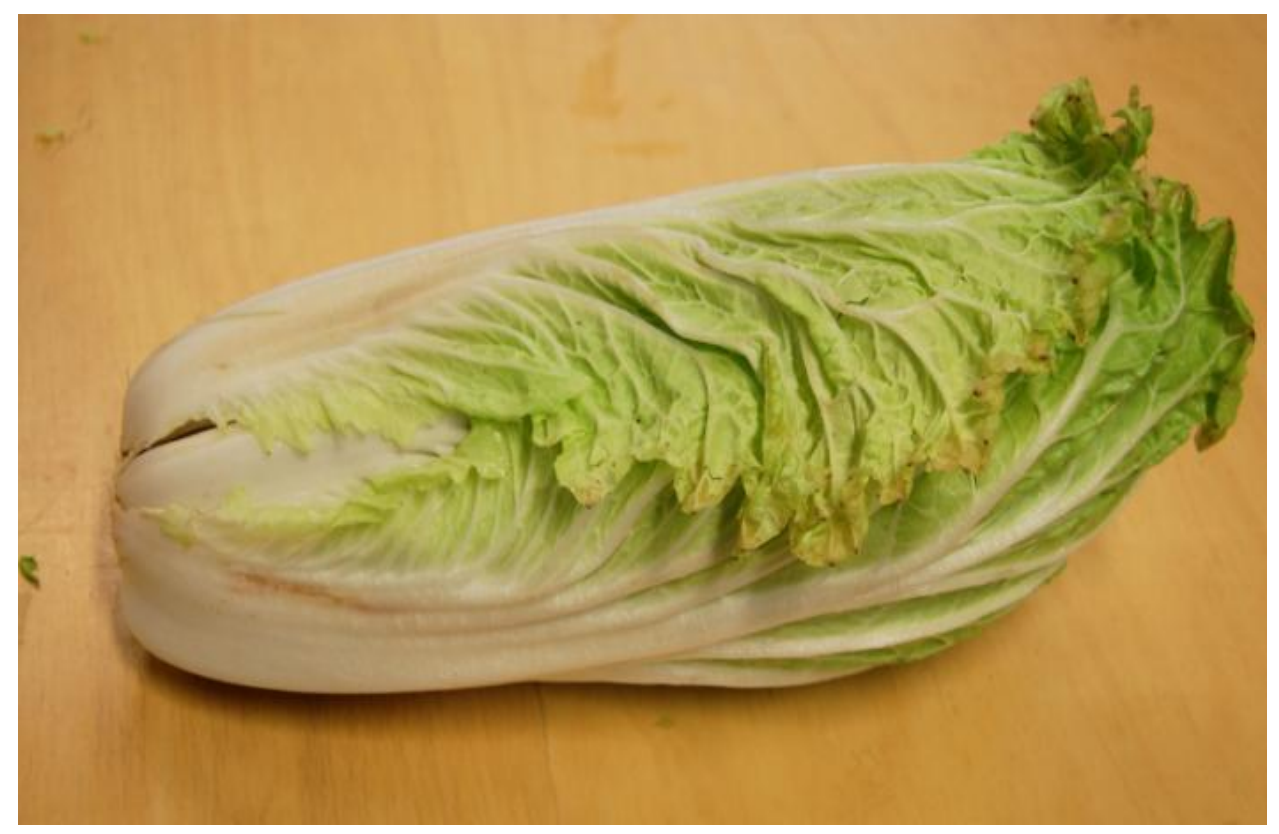

Kuva 6. Kiinankaalin lajikekokeella esiintynyttä lehden reunojen ruskettumista ja mustapilkkuisuutta. (Kuva: Hanna Avikainen)

\section{Johtopäätökset}

Kasvukausi 2011 oli alussa sääolosuhteiltaan lämmin ja kuiva, mikä nopeutti varsinkin parsakaalin lajikekokeen kehitystä. Heinäkuun helteet ja ajoittain korkea ilmankosteus aiheuttivat jäävuorisalaattikokeella tautipainetta. Syyskuun runsaat sateet puolestaan lisäsivät kiinankaalin lajikekokeella lajikkeiden lajikkeiden tautiriskiä.

Koska monet jäävuorisalaattilajikkeet ovat olleet kokeissa vasta yhtenä tai kahtena kasvukautena, niin koetuloksiin on syytä suhtautua varauksella. Varsinkin kun kasvukauden 2010 lajikokeen tulokset eivät olleet luotettavia salaatille vaikeiden kasvuolosuhteiden vuoksi.

Parsakaalilajikkeista Koros ja Chronos ovat olleet kokeissa kahtena tai kolmena kasvukautena ja niistä on hyviä kokemuksia niin sadon määrän kuin laadunkin suhteen. Myös Sirtaki on ollut kokeissa kolmena kasvukautena. Sen ongelmina ovat olleet epätasainen laatu ja onttovartisuus, mutta lyhyen kasvuajan vuoksi sen viljely on suositeltavaa.

Kiinankaalilajikkeiden osalta kahden kasvukauden tulokset ovat olleet keskenään ristiriitaisia. Kasvukauden 2010 kokeessa menestyneet TEHA ja Suprin eivät kasvukauden 2011 kokeessa vakuuttaneet. Jotta uusista lajikkeista voi antaa suosituksia, tarvitaan lisää lajikekokeita.

Avomaan vihannestuotannon kehittymisen kannalta olisi eduksi se, että vihannesten lajikekokeista tulisi osa valtiollisen tutkimusorganisaation toimintaa, eikä niitä toteuttaisi ainoastaan maaseudun kehittämishankkeiden ja viljelijöiden toimesta. 


\section{Kirjallisuus}

Puutarhatilastot 2010, Maa- ja metsätalousministeriön tietopalvelukeskus, Helsinki, 2011

Hintikainen,V., Tillanen, A., Arola, Johanna.\& Avikainen Hanna. 2011. Kiinankaalilajikkeiden säilyvyys vaihteli. Puutarha \& kauppa 4/2011: s. 20.

Hintikainen,V., Tillanen, A., Arola, Johanna.\& Avikainen Hanna. 2011. Parsakaali kärsii kasvukauden säävaihteluista. Puutarha \& kauppa 6/2011: s. 20 